\title{
ODIOUS DEBT, ODIOUS CREDIT, ECONOMIC DEVELOPMENT, AND DEMOCRATIZATION
}

TOM GINSBURG*

THOMAS S. ULEN**

INTRODUCTION

Consider an all-too-common story. A dictator of a poor country borrows liberally from international donors, nominally to fund development projects. Some fraction goes to development projects, but a larger share ends up in the hands of the elites who are part of the dictator's governing coalition or in the dictator's Swiss bank account. At the same time, the dictator is misgoverning the country, not undertaking health and educational expenditures that could enhance the well-being of the citizens of the country, further enriching himself and his supporters from domestic sources. As the foreign debt and the dictator's personal riches add up, it increasingly looks as if the debt cannot be paid. Lending stops, the dictator's government collapses, and the country struggles to establish new democratic institutions. The new democracy tries to make the debt payments but finds that they draw away from necessary spending on social services to meet pent-up demands. The government becomes unstable; the democracy waivers and eventually collapses.

In this story, the dictator has taken not just the present but also the future, dooming the country's democratic institutions in their infancy. Why then should the new democratic government pay the dictator's debts, even those made in the name of the nation? To put it in more concrete terms, why should the citizens of Zaire be saddled with the debt of Mobutu Sese Seko, under whom the country accumulated over $\$ 12$ billion in sovereign debt, while Mobutu's personal assets reached $\$ 4$ billion? Why should Filipinos today be responsible for the $\$ 28$ billion in sovereign debt left by Ferdinand Marcos, who left his heirs a personal fortune of $\$ 10$ billion?

\footnotetext{
Copyright (C) 2007 by Tom Ginsburg and Thomas S. Ulen.

This article is also available at http://law.duke.edu/journals/lcp.

* Professor of Law, University of Illinois College of Law, and Director, Illinois Program on Asian Law, Politics, and Society.

** Swanlund Chair, University of Illinois at Urbana-Champaign, and Professor of Law, University of Illinois College of Law, and Director, Illinois Program on Law and Economics. The authors would like to thank Amber Danielle Evans for excellent research assistance.
} 
The standard international-law response is that states, not governments, are responsible entities. ${ }^{1}$ So, for instance, when a country signs an international treaty, it is not the government but the state that is bound, and the obligation will stand until a subsequent government formally exits the treaty. Exit is presumed to be costly: a government that "repudiates" earlier treaty obligations will suffer reputational harm in its international relations. ${ }^{2}$ This general background norm of international law applies as well to debt: a government can announce that it is renouncing debt, but it will suffer severe reputational harm in the debt marketplace, much as a government that repudiates public international law obligations suffers a reputational harm. In addition, assets of the repudiating state can be seized abroad, so there will be real enforcement of the obligation. There is, as yet, no form of sovereign bankruptcy to allow debtor nations to escape obligations. ${ }^{3}$

\section{A. The Odious Debt Problem}

At times, major powers-invoking what has come to be known as the doctrine of "odious debt"-have argued that new regimes should not be responsible for debts incurred by old ones. After the Spanish-American War, for example, the United States argued that neither Cuba nor the United States should be responsible for debt incurred by the colonial Spanish government. In the famous Tinoco Arbitration of 1923, the panel suggested that credits knowingly extended to a country for a dictator who used the money for his personal purposes should not be recoverable. ${ }^{4}$ Recently, the fall of Saddam Hussein in Iraq has prompted renewed calls for reviving this doctrine and creating an odious debt exception to state succession. ${ }^{5}$ Despite these incidents,

1. See generally IAn Brownlie, Principles of Public International LaW (6th ed. 2003).

2. One example is the Argentinean experience with reneging on international debt obligations. PAul Blustein, AND THE Money KePt Rolling Out (AND IN) (2006).

3. See generally Conference, Sovereign Debt Restructuring: The View from the Legal Academy, 53 EMORY L.J. 657, 657-1218 (2004) (examining potential methods of sovereign-debt restructuring); Andrew T. Guzman, Colloquy: International Bankruptcy: In Defense of Universalism, 98 MICH. L. REV. 2177 (2000) (evaluating universal and territorial approaches to the adjudication of international insolvencies).

4. Arbitration Between Great Britain and Costa Rica, 1 U.N. REP. INT'L. ARB. AwARDS 369, 37576 (1923), reprinted in 18 AM. J. INT’L L. 147, 148 (1924).

5. For some of the recent literature, see generally PATRICIA ADAMS, OdIOUS DEBTS: LOOSE LENDING, CORRUPTION AND THE THIRD WORLD'S ENVIRONMENTAL LEGACY (1991) (reviewing the history of odious lending); Joseph Hanlon, "Illegitimate Debt": When Creditors Should be Liable for Improper Loans, in SOVEREIGN DEBT AT THE CROSSROADS 109 (Chris Jochnick \& Fraser A. Preston eds., 2006) (focusing on the odiousness of lending regardless of the status of the borrower); Anna Gelpern, What Iraq and Argentina Might Learn from Each Other, 6 CHI. J. INT'L L. 391 (2005) (analyzing sovereign debt in Iraq and Argentina); Seema Jayachandran \& Michael Kremer, Odious Debt, 96 AM. ECON. REV. 82 (2006) (arguing that loan sanctions, unlike trade sanctions, may prevent odious debt); Ashfaq Khalfan, Jeff King \& Bryan Thomas, Advancing the Odious Debt Doctrine (Ctr. for Int'l Sustainable Dev. Law, Working Paper, 2003), available at http://www.odiousdebts.org/ odiousdebts/publications/Advancing_the_Odious_Debt_Doctrine.pdf (defining odious debt and arguing for cancellation of odious debt under international law); see also FOREIGN POLICY, Ranking the Rich, FOREIGN POLICY, Sept.-Oct. 2006, at 68, 70 (discussing Iraqi and Nigerian loan write-offs); 
the international community has not yet adopted a general doctrine of excusing odious debts. Rather, the default rule is that sovereign debt is to be repaid, regardless of the circumstances under which it was contracted or for which the debt was used. Whereas international powers may act in an ad hoc way to assume or restructure sovereign debt of favored countries, no general off-theshelf doctrine is available to be applied in a neutral manner across cases. ${ }^{6}$

\section{B. Three Responses}

Scholars who have recognized the odious debt problem have proposed several creative solutions. Of these, three general forms of proposed solutions can be identified.

\section{The "Do Nothing" Approach}

The most elemental of the proposed solutions to the problem of odious debt-one to which very few tie their flags-is simply to do nothing. An alternative way of stating much the same position is to hold that sovereign debt is always to be enforced. ${ }^{8}$ If that is the clear rule governing these matters, then all parties in this market are on notice and can make their own calculations of expected cost and benefit. The market for international debt is a sophisticated and ongoing competitive market. There is no obvious source of market failure that calls for correction. In essence, this position holds that odious debt presents no systematic problem in international law and relations requiring a novel institutional, policy, or legal solution.

An argument in favor of a clear rule for the enforceability of sovereign debt begins with the observation that the parties involved in lending and borrowing money in international debt markets are sophisticated. They understand how to evaluate risk, including the risk of default; how to use contractual language and legal processes to protect themselves; and how to appeal to public bodies for relief if the law is unavailing. As a result, lenders who extend credit to nations ruled by despots whose successors might seek to repudiate the debt can hardly

Lee. C. Buchheit, G. Mitu Gulati \& Robert B. Thompson, The Dilemma of Odious Debts, 56 DukE L.J. 1201, 1208-24 (2007) (addressing the taxonomy of sovereign debt).

6. Odious debt can be seen as a special case of the more general problem of debt relief, which is an issue raised by many developing countries that cannot meet their debt burden. See, e.g., Ellen Johnson Sirleaf \& Paul Wolfowitz, Lift Liberia's Debt Burden, WALL ST. J., Feb. 13, 2007, at A25.

7. See generally Albert H. Choi \& Eric A. Posner, A Critique of the Odious Debt Doctrine, 70 LAW \& CONTEMP. PROBS. 33 (Summer 2007) (suggesting that the overall effect of the application of the current odious debt doctrine could potentially be negative and stating a need for more empirical work before instituting the doctrine).

8. One might argue that the opposite rule - that sovereign debt is never enforceable - would also, under the appropriate assumptions, lead to an optimal state of affairs. This is simply an exercise in the application of the Coase Theorem, which examines economic efficiency through the allocation of property rights and considerations of transaction costs. Note, though, that there is some evidence that enforceability of sovereign debt played a key role in early capitalism, underpinning the industrial revolution. See, e.g., Douglass C. North \& Barry R. Weingast, Constitutions and Commitment: The Evolution of Institutions Governing Public Choice in Seventeenth-Century England, 49 J. ECON. HISTORY 803 (1989). 
complain that they were unfairly surprised by this turn of events. Rather, those lenders could plausibly be thought to have willingly assumed the risk of nonpayment: they assessed the likelihood of a default's occurring and took (or could have easily taken) steps-such as self- or market-insurance-to protect themselves from loss.

Despots seeking loans are equally adept at assessing their market opportunities and, no doubt, seek the best deal that they can, subject to the obvious fact that lenders want to be repaid. If a despot repeatedly uses loans for purposes other than those for which it was loaned, his access to international debt markets might be compromised. To the extent that despots are repeat players in the international debt market, they have an incentive to be reasonably truthful and relatively transparent to the lending community.

If the market for international debt "works" in the sense that all relevant information is available, all parties are well informed, and there are no obvious market imperfections, then there is no particularly compelling case for thirdparty intervention.

However, there might be an external cost to a despot's loans taken out in the name of his country - a cost born by the citizens who may be obliged to repay the loans after the despot's departure. Those citizens cannot be fairly inferred to have approved of the despot's loans-unless, of course, those loans were used for public projects. That is, if the despot's loans were incurred, as in some of the examples above, to enrich the despot or for the furtherance of some folly-uses for which a democratically elected government would have been extremely unlikely to have incurred international debt-then there is no principled argument (other than that laid out in Part II) for the nation's citizens to be held responsible for those debts. They could not meaningfully (as through election, public pressure on legislators, or expressions of displeasure in public fora) have prevented the loans from being incurred. And it is unlikely to be the case that the dictator's loan activity is a triggering action for regime change. Dissatisfaction with that aspect of a despot's rule might have been relatively minor in the list of complaints - that is, perhaps not enough of a dissatisfaction to warrant armed rebellion. So, the citizens are simply stuck with responsibility for a despot's debts incurred in the name of the nation, or hopeful of simply reneging on the loans without damaging the nation's access to credit.

At first blush, this externality argument might seem to defeat the "do nothing" solution in favor of some internationally mediated, institutional method of dealing with odious debt. But further consideration might suggest that even the presence of unfairly burdened citizens is not really a cause for an international institutional solution; it might be the case that international donors, organizations, or nations might step in to relieve unfairly burdened citizens of responsibility for sovereign debt incurred by a former dictator.

Consider this scenario. Saddam Hussein, while the dictator of Iraq, incurs billions of dollars in loans, ostensibly for legitimate public purposes but, in reality, for unsupportable purposes. He is toppled by a U.S. invasion, and an 
unstable but roughly democratic government takes over administration of the country. The "do nothing" solution would argue in favor of this new government's assuming the debt obligations of the Hussein government. And naturally the lenders who are owed millions argue that the new government has the resources to discharge these obligations. For example, in theory the new government can now sell oil freely to international buyers, something that the Hussein government could not legitimately do because of United Nations sanctions. But, just as naturally, the new democratic government argues that it should not have to discharge these obligations. It has obligations to rebuild the country from the invasion and from years of neglect under Hussein; to build or reconstruct schools, roads, hospitals, water and sewerage infrastructure; and so on. If the new, democratically elected government were obliged to discharge Hussein's debts, it would have much less revenue left to undertake the nationbuilding that will make the democratic government more stable.

Suppose that there are some extraordinarily large international private enterprises that believe that if Iraq is stabilized, significantly profitable economic opportunities will result. They might therefore be willing to extend loans to the new Iraqi government on very favorable terms, independent of what is done about the problem of Hussein's odious debt. Moreover, these international private enterprises might have sufficient political capital to persuade the lenders, who are expecting to be repaid, either to refinance or forgive portions of the outstanding debt or to persuade their home country governments to find some method of relieving the new government of the burden of Hussein's debt.

The general lesson of this brief scenario is that the possibility of future economic profit in a newly democratic nation and the exertion of international political power might relieve the unfairly burdened citizens of a national obligation to repay sovereign debt. One might further predict that these forces will come into play in precisely the circumstances in which the burden of odious debt would be most likely to harm the prospects of a new government. ${ }^{9}$

\section{The Ex Ante Approach}

The second class of solutions to the problem of odious debt is to try to identify and deal with the problem ex ante through a formal mechanism. ${ }^{10}$ In general, this would provide some method of identifying portions of new

9. This is a variant on the position for which we shall ultimately be arguing. To foreshadow that position, we find some attraction in the scenario we have just painted-that is, one in which there are forces compelling the relief of the burden of odious debt in those circumstances in which holding a nation to sovereign obligations threatens a democratic government. But we are not sufficiently sanguine about this possibility to leave these matters to chance. Efforts to provide relief in this manner may be subject to collective action problems among those seeking to do so. So, we argue in favor of a more explicit relationship between forgiveness of odious debt and the process of democratization.

10. See, e.g., Jayachandran \& Kremer, supra note 5, at 1. 
sovereign debt that would (and those that would not) survive a regime change. ${ }^{11}$ Because the borrower-in this instance, a despot-would not have the appropriate incentives to reveal his true intentions for the loan, identifying the points of bargaining could not be left to the parties. Rather, some neutral third party (or tribunal) (12 $^{2}$ would have to identify which fraction of the loan was odious debt and which was not, or which regimes would be characterized as presumptively odious. This would have to be done early enough in the bargaining process between lender and borrower that the terms and conditions of the loan-say, its interest rate-could be adjusted in light of the tribunal's findings. The theory is that by identifying odious debt ex ante, there will be not only a chilling effect on both lenders and borrows in extending odious debt, but also fewer grounds for dispute later on.

One interesting question is when a regime should be labeled as odious. ${ }^{13}$ On the one hand, labeling a regime as odious early in its tenure is likely to minimize damage from the regime's bad performance. On the other hand, waiting will reduce the risk of mislabeling a regime, as more information on odiousness becomes available. Furthermore, waiting will make international consensus easier to develop and will minimize market uncertainties. There is also the problem of regime behavior shifting over time. It is likely that rulers with shorter time horizons will be more prone to looting their countries. This complicates the time calculation for assessing odious debts.

Although it is not impossible that this ex ante certification scheme could develop into a viable method of dealing with the problem of odious debt, its effectiveness is doubtful. The evidentiary basis on which to designate portions of a loan package as odious ex ante is not at all obvious. There are several reasons for this belief.

First, no borrower, despotic or otherwise, is going to reveal in complete candor what he intends to do with the proceeds of an international loan, and he will certainly be wise enough not to reveal odious aspects of the loan. Even Saddam Hussein was able to convince U.N. inspectors that he was using sequestered oil sale revenues for humanitarian purposes, a claim now known to be very wide of the truth. ${ }^{14}$ Surely the borrower will be able to manufacture all sorts of attractive public projects for which he needs international loans, while concealing the real plans for the money. And it is unlikely to be easy for lenders to make inquiries that will reveal the true plans for the funds.

The second reason that evaluating debt packages ex ante is so difficult is the absence of any metric by which the rule can realistically or should in theory be

11. In current practice, either all of a sovereign debt is deemed odious or none of it is. For the purposes of this article, however, the assumption will be made that fractions of debt can be designated odious and nonodious.

12. See Jayachandran \& Kremer, infra note 15 (proposing a tribunal for this purpose).

13. Stephania Bonilla, A Law-and-Economics Approach to Odious Debts 20-22 (paper prepared for 23rd EALE Conference, Madrid, Spain, 2006, on file with authors).

14. See JefFrey A. Meyer \& MARk G. Califano, Good Intentions Corrupted: The OiL FOR FOOD SCANDAL AND THE THREAT TO THE U.N. (2006). 
applied. Will (or should) the tribunal give an overall odious score to the loan on, say, a one-to-ten scale? Will (or should) it be the case that if some portion of a loan package is deemed odious, then the entire package should be deemed odious? And what would or should the threshold be for determining what proportion of a loan package's odious provisions deems the entire package odious - twenty percent by value, thirty-three percent, fifty percent?

Furthermore, even if the tribunal did succeed in designating a particular debt offering as "odious," it is doubtful that this would estop subsequent disputes between the lenders and the country if there were regime change. Indeed, litigation galore about such matters as whether the tribunal adequately considered all the evidence or whether the assertions of the despot-borrower were treated skeptically enough would likely ensue. These ex post disputes are all the more likely in view of lenders' limited opportunities to monitor the borrower's behavior during the course of the loan. So, if odious uses of a loan come to light, they are only likely to be revealed after the despot has left the scene, and by the efforts of the successor government.

\section{The Ex Post Approach}

The third and final class of solutions to the problem of odious debt is to deal with the problem ex post. The most frequent suggestion of this sort is to create an international tribunal to adjudicate between lenders and nations regarding whether the unpaid sovereign debt is odious. ${ }^{15}$ Just as the ex ante designation of all or part of sovereign debt as odious is fraught with problems of administrability, so, too, is the ex post adjudication of sovereign debt as odious and, therefore, excusable. No doubt interest rates would increase because of the risk of being declared odious in the future or of being mistakenly labeled "nonodious." Whereas interest rates would increase more steeply for the authoritarian regimes that had the potential to be labeled odious, all borrowers would have to pay increased rates. Ironically, this effect might be hardest on poorer countries, for which the marginal cost of interest rate increases is higher. It is possible, however, that the administration costs of this ex post demonstration would be less than those of the ex ante designation. The central claim would likely be that the loans had been acquired under fraudulent pretenses - an allegation that is reasonably easy to demonstrate-as opposed to the exceedingly difficult ex ante demonstration that the loans were not those that a duly elected democratic government would have entered into in the first place.

15. Michael Kremer \& Seema Jayachandran, Odious Debt, BRoOKINGS InstituTiOn PoliCy BRIEF \#103 (July 2002) (calling for a third-party adjudicator to determine whether debt is odious), http://www.brookings.edu/comm/policybriefs/pb103.htm; Patrick Bolton \& David Skeel, Odious Debts or Odious Regimes? 70 LAW \& CONTEMP. PROBS. (forthcoming Autumn 2007). 
4. An Alternative Approach: The Roles of the "Odious Creditor" and of Economic Development and Democratization

Unfortunately, none of these proposals for dealing with indefensible sovereign debt has commanded, or is likely to command, a majority scholarly or public following. Odious debt is still a major policy problem, and this article proposes alternative mechanisms for finding a solution.

This article recognizes two dimensions of the odious debt problem that have received too little attention-the potential role of the "odious creditor" and the connection between obligations to repay sovereign debt and the process of economic development and democratization. First, consider the role of "odious creditors," which we define as government creditors willing to make loans to despots as part of a calculated strategy of national politics. One example is the Chinese government's support for the regimes in the Sudan, which itself is associated with the ongoing genocide in Darfur. China has extended billions of dollars in loans to the Sudanese government in an effort to secure a favored position as a buyer of natural resources. Needless to say, China would be unlikely to support debt forgiveness should a democratic regime ever emerge in the Sudan. The odious creditor complicates the development of solutions to the problem of odious debt. Recognizing this connection between international relations and the problem of odious debt casts doubt on the workability of the ex ante and ex post structural solutions discussed above.

Second, there is an explicit connection between the problem of odious debt and the related processes of economic development and democratization. The arguments in favor of furthering economic development are so obvious and those in favor of democratization are so compelling that a sensible solution to the issue of odious debt should explicitly consider the extent to which forgiveness of odious debt can significantly further these objectives.

The arguments for approaching the odious debt problem are made here in several stages. Considered first, as a threshold point, is the quasi-constitutional issue of why state succession makes sense in international law and how carving out an exception to this doctrine affects the development and democratization of debtor nations. Second, this article briefly examines the arguments in favor of economic development and the role of democratization in development. Third, the article discusses the odious creditor problem and argues that it is unlikely that international law will ever acknowledge an odious debt doctrine as a general matter. We also express skepticism about the United Nations as a forum for addressing the issue. Fourth, this article elaborates on what we believe is a workable solution that relies on existing institutions and avoids the problem of the odious creditor. A concluding section summarizes.

II

\section{WHY STATE SUCCESSION TO INTERNATIONAL OBLIGATIONS IS NECESSARY}

A threshold question in the odious debt debate is why states ought to be responsible at all for debts incurred previously. That is, why should today's 
citizens ever be responsible for earlier debts incurred by their political predecessors? Mitu Gulati and his co-authors deal with this issue in their article on the taxonomy of debt, pointing out that one reason to support successor liability is that the successors have benefited from the earlier investments. ${ }^{16}$ This presents a morally unproblematic case. In other cases, such as the kind of debt labeled odious, it is not so obvious why the successors should be obligated. They have not, after all, benefited at all from the money, nor did they have a role in choosing the rulers who made the decision to borrow. Rather, they simply had the bad luck of succeeding bad rulers, and their populations the misfortune of having been "born under a bad sign."

One needs, then, a broader theory of how state succession relates to democracy. An initial argument is that state succession facilitates international exchange and domestic state-building by facilitating credible commitments. ${ }^{17}$ The intuition is simple: a promise at Time 1 has value only if the promisee believes that it will be obeyed at Time 2 . For governments that enter into treaty commitments, their counterparts may be unwilling to count on the obligation's being upheld if subsequent governments might not perform the promise. This problem is particularly acute when the promising state actors are uncertain about the incentives they, themselves, will face in the future. ${ }^{18}$ If costs and benefits vary in unpredictable ways, a politician's promise to behave in a specified way may be less believable. A doctrine of state succession facilitates international cooperation by making the promises of all states more believable to other states. ${ }^{19}$

Note that the function of state succession is more important for democracies than for dictatorships. Democracies are by definition characterized by governments that come and go. Dictators do go but typically have a longer time horizon than democratic governments. For example, the Chinese Communist Party has been able to make sufficiently credible promises to attract massive amounts of foreign investment even in the absence of an independent legal system. Investors understand that the Party, like the House of Saud and other institutionalized authoritarian regimes, has a long time horizon. If the doctrine

16. Buchheit et al., supra note 5, at 6-21 (addressing the taxonomy of sovereign debt).

17. For scholars making this argument, see, e.g., JON ELSTER, UlySSES AND THE SIRENS: STUDIES IN RATIONALITY AND IRRATIONALITY 36-111 (1979); JON ELSTER, ULYSSES UNBOUND: STUDiES IN RATIONALITY, PRECOMMITMENT AND CONSTRAINTS 129-41, 157-61 (2000); STEPHEN HOLMES, PASSIONS AND CONSTRAINT: ON THE THEORY OF LIBERAL DEMOCRACY 134-77 (1995); Stephen Holmes, Precommitment and the Paradox of Democracy, in CONSTITUTIONALISM AND DEMOCRACY 195-240 (Jon Elster \& Rune Slagstad eds., 1988). But see JEREMY WALDRON, LAW AND DISAGREEMENT (1998) (arguing that disagreements should be solved by decisionmaking between right-holders); Jeremy Waldron, Precommitment and Disagreement, in CONSTITUTIONALISM 271-99 (Larry Alexander ed., 1998) (criticizing Holmes and Elster).

18. See generally GeORGE W. DOWNS \& DAVID M. ROCKE, OPTIMAL IMPERfECTION? DOMESTIC UNCERTAINTY AND INSTITUTIONS IN INTERNATIONAL RELATIONS (1995) (exploring domestic uncertainty through information games and game theory).

19. Of course subsequent governments can exit the obligations by withdrawing from or denouncing the treaties that contain the commitments. Doing so, however, entails political costs. See Laurence R. Helfer, Exiting Treaties, 91 VA. L. REV. 1579 (2005). 
of state succession did not exist, then democracies would be at a disadvantage in the international sphere because contractual counterparts would be less willing to trust that the successor governments would uphold the obligation.

An underappreciated dimension of state-succession doctrine is that it not only facilitates commitment to international audiences, but also to domestic ones. That is, politicians may in some circumstances choose to convey promises to domestic constituents in international instruments rather than in domestic ones. Consider this negative example: by joining the World Trade Organization, politicians signal to domestic constituents their inability to enact special protections for domestic producers against foreign competitors. In this sense, some international agreements parallel national constitutional structures. ${ }^{20}$ International obligations are particularly attractive in some circumstances precisely because of state succession to obligations. Political actors who have trouble making credible commitments in the domestic sphere may prefer to make promises through an international obligation. This feature is, however, particularly crucial for new democracies and new states that have few other means of making credible promises. ${ }^{21}$ Thus, state succession to international obligations helps increase the power of those commitments that states do enter into, facilitating both international cooperation and domestic constitutionalism.

This form of commitment beyond the state is particularly useful for new democracies. Imagine a newly democratic government that emerges after an authoritarian regime and promises to protect the human rights of its own citizens. The citizens might believe the government, but they might also be concerned that the promise will not be kept by the new government's successors. The government can make its promise more credible by embedding it in an international treaty to respect human rights. Any future government that violates the human rights of its citizens will suffer some form of sanction, either as an effect on its international reputation or possibly even as formal enforcement mechanisms. This helps explain why new democracies are particularly prone to include provisions for international obligations in their constitutions: state succession facilitates democratic commitments.

20. CAss Sunstein, What Constitutions Do 241 (2001) ("Democratic constitutions operate as 'precommitment strategies' in which nations, aware of problems that are likely to arise, take steps to ensure that those problems will not arise or that they will produce minimal damage if they do."); see also FRIEDRICH A. HAYEK, THE CONSTITUTION OF LIBERTY 179 (1960) ("[The reason for constitutions] is that all men in the pursuit of immediate aims are apt—or, because of the limitation of their intellect, in fact bound - to violate rules of conduct which they would nevertheless wish to see generally observed. Because of the restricted capacity of our minds, our immediate purposes will always loom large, and we will tend to sacrifice long-term advantages to them."); STEPHEN HOLMES, PASSIONS AND CONSTRAINT: ON THE THEORY OF LIBERAL DEMOCRACY 135 (1995) (arguing that constitutional restraints facilitate democracy and that liberal theory provides a foundation for democratic government); A.C. Pritchard \& Todd J. Zywicki, Finding The Constitution: An Economic Analysis Of Tradition's Role In Constitutional Interpretation, 77 N.C. L. REV. 409, 447-49 (1999) (discussing the efficiency purposes of constitutionalism, including precommitment).

21. Tom Ginsburg, Locking in Democracy: Constitutions, Commitment and International Law, 38 NYU J. INT'L L. \& POLITICS 707 (2006). 
One could, of course, carve out a category of international obligations that should not be honored. But such a carve-out would undercut the making of commitments by those states most in need of credibility, namely new democracies. These states will find that their credibility for both domestic and international audiences is more enhanced if there are fewer carve-outs that are more rarely invoked. ${ }^{22}$

Furthermore, as previously mentioned, a carve-out creates administrative problems-mainly those of developing a principled set of criteria for distinguishing odious from nonodious debt. After all, odious debts can be "laundered" by international financial institutions (IFIs), as in the case of the Congo after dictator Mobutu Sese Seko left the country in arrears to the International Monetary Fund (IMF). ${ }^{23}$ Several governments gave the Congo bridging loans to repay the IMF, which then extended new credit for the Congo to repay the donating countries for the bridging loans. ${ }^{24}$

In short, state succession is a useful doctrine, not just for promisees but also for promisors. Credibility helps precisely those countries that lack other mechanisms for making promises believable, both to international and domestic audiences. Efforts to create a carve-out regime are noble, but have substantial line-drawing problems. Furthermore, any plausible and administrable carve-out will likely increase the price of debt for all countries because it introduces additional uncertainty in the debt market.

III

\section{ECONOMIC DEVELOPMENT AND DEMOCRATIZATION}

Because economic development and democratization are necessary criteria for dealing with the doctrine of odious debt, it is worthwhile, very briefly, to make the case for development and democracy and the link between them. In Integrating a Theory of the State and Sovereign Debt Restructuring, ${ }^{25}$ Robert Rasmussen identified the necessary connection between a nation's governance system and the desirability of restructuring the nation's debt when there is distress from sovereign-debt service. That analysis can be extended to the particular problems associated with economic development and odious debt.

The case in favor of economic development is almost too obvious to need elaboration. ${ }^{26}$ Nonetheless, briefly put, there are a significant number of people whose lives would be greatly improved by additional income and wealth. The

22. An unintended consequence of any carve-out regime is that it will increase debt prices for all, odious or not.

23. Joseph Hanlon, 'Illegitimate' Loans: Lenders, Not Borrowers, Are Responsible, 27 THIRD WORLD Q. 211 (2006); Hanlon, supra note 5, at 123.

24. Id.

25. See Robert Rasmussen, Integrating a Theory of the State and Sovereign Debt Restructuring, 53 EMORY L.J. 1159 (2004).

26. See The World Bank, PovertyNet Overview, http://web.worldbank.org/WBSITE/EXTERNAL/ TOPICS/EXTPOVERTY/0,,contentMDK:20153855 menuPK:373757 pagePK:148956 piPK:216618 t heSitePK:336992,00.html (last visited May 22, 2007). 
World Bank has established two threshold measures of poverty-living on one dollar or two dollars per day-and reports that nearly half of the earth's population is living at or below the latter level. The costs of poverty itself are daunting, from dramatically high rates of infant mortality and illness ${ }^{27}$ to dramatically low life expectancies. ${ }^{28}$ And yet, amazingly, it is trivially inexpensive to address most of the issues-infant mortality, disease, and malnutrition - resulting from extreme poverty. ${ }^{29}$ At a minimum, being wealthier means being healthier. To put this dramatically, a study by Lant Pritchett and Larry Summers found that "the deaths of about half a million children in 1990 would have been averted if Africa and Latin America's growth in the 1980s had been 1.5 percentage points higher.", ${ }^{30}$

Not only is economic development better in terms of eradicating the effects of poverty, but development is better for citizens' psyches. The evidence is accumulating on the relationship between self-reported happiness and per

27. William Easterly makes a compelling case for why poverty is to be avoided: "The typical rate of infant mortality in the richest fifth of countries is 4 out of every 1,000 births; in the poorest fifth of countries, it is 200 out of every 1,000 births. Parents in the poorest countries are fifty times more likely than in the richest countries to know grief rather than joy from the birth of a child.... The higher rates of babies dying in the poorest countries reflect in part the higher rates of communicable and often easily preventable diseases such as tuberculosis, syphilis, diarrhea, polio, measles, tetanus, meningitis, hepatitis, sleeping sickness, schistosomiasis, river blindness, leprosy, trachoma, intestinal worms, and lower respiratory infections. At low incomes, disease is more dangerous because of lower medical knowledge, lower nutrition, and lower access to medical care. WILLIAM EASTERLY, THE ELUSIVE QUEST FOR GROWTH: ECONOMISTS' ADVENTURES AND MisADVENTURES IN THE TROPICS 8-9 (2001).

28. Statistics from the HUMAN DEVELOPMENT REPORT 2003 indicate differences in life expectancies vary dramatically across regions and countries: life expectancy at birth in Sierra Leone today is 34.5 years, whereas it is 81.3 years in Japan. U.N. DEVELOPMENT PROGRAMME, HUMAN DEVELOPMENT REPORT 2003: MiLlenNiUM DEVELOPMENT GOAls: A COMPACT AMONG NATIONS TO END HUMAN POVERTY 237, 240, available at http://hdr.undp.org/reports/global/2003/. Another measure of this can be found in our own history. In 1900 the combined average life expectancy for men and women in the United States was 47.3 years. CENTERS FOR DisEASE CONTROL AND PREVENTION, HEALTH, UNITED STATES 2006 176, available at www.cdc.gov/nchs/data/hus/hus06.pdf\#027. Approximately one hundred years later, in 2001, the average life expectancy for males was seventy-four years and for women, eighty years. $I d$. at 310 . And it is said that a female baby born today in Japan or France has a fifty percent change of living to one hundred. See Jim Oeppen \& James W. Vaupel, Broken Limits to Life Expectancy, 296 SCI. 1029 (2002); James Meek, Health Crisis Looms as Life Expectancy Soars, GUARDIAN, May 10, 2002, available at http://www.guardian.co.uk/medicine/ story $/ 0 \% 2 \mathrm{C} 11381 \% 2 \mathrm{C} 713141 \% 2 \mathrm{C} 00 . \mathrm{html}$ (explaining Vaupel's extrapolated findings).

29. Oral-rehydration therapy, which would address the issues of dehydration caused by, among other things, diarrhea, costs less than ten cents per dose. Rehydration Project, Oral Rehydration Salts, http://rehydrate.org/ors/index.html (last visited May 22, 2007). Vaccinations against a range of debilitating diseases-pertussis, polio, diphtheria, measles, and tetanus-cost between twenty and thirty dollars per child. UNICEF, Facts on Children: Immunization, http://www.unicef.org/ media/media_9479.html (last visited May 22, 2007). Vitamin A capsules cost about two cents each. UNITED NATIONS CHILDRENS FUND, WORLDMUN ISTANBUL 2001 at 5, available at http://www.worldmun.org/2006/archives/01/xcomunicef.pdf. Iodizing salt supplies cost about five cents per affected person per year. ASIAN DEVELOPMENT BANK, ASIAN DEVELOPMENT BANK REVIEW 2005, available at http://www.adb.org/Documents/Periodicals/ADB_Review/2005/vol37-4/simplesolutions. asp (last visited May 22, 2007). And intestinal parasites can be cured with inexpensive drugs.

30. Lant Pritchett \& Lawrence Summers, Wealthier is Healthier (World Development Report, Working Paper No. 36, 1993), available at http://www-wds.worldbank.org/servlet/WDSContentServer/ WDSP/IB/1993/06/01/000009265_3961004215604/Rendered/PDF/multi0page.pdf. 
capita income. The World Values Survey of over 100,000 people in over ninety countries, including developing countries, found a robust correlation between increases in per capita income and self-reported happiness. ${ }^{31}$ Somewhat less obvious is the connection between economic development and democratization. There is a consensus among students of economic growth-a belief known as the "Lipset hypothesis" - that democratization is not a precondition for the early stages of development. ${ }^{32}$ Indeed, there is some evidence that democracy may make the early stages of growth faltering and messy. ${ }^{33}$ Powerful individuals and interest groups may use the nascent democratic process to their advantage, while the ability of the government to implement public-spirited reforms may be severely limited. So, in the early stages of growth, it may well be the case that an enlightened despotism is more efficient than a new democracy.

Eventually, however, democracy may be necessary for sustained economic growth. This may be the case when the government has become more mature in its ability to resist blandishments from powerful individuals and interest groups or when corruption has been brought under control. An additional virtue of democracy at a later stage is that a large enough number of interest groups may have formed so that politics can provide a competitive arena in which no one group or coalition is able to dominate the governmental structure. Some theorists claim that an example of this in a developing society is when an urban commercial class becomes strong enough to grab a share of democratic power away from the landed interests who controlled the society before development began in earnest. ${ }^{34}$

31. See World Values Survey, European and World Values Surveys Four-Waive INTEGRATED DATA FILE 1981-2004 (2006), available at www.worldvaluessurvey.org (follow "Findings" link, then "Collection of Graphs Presenting WVS Data" link to the tenth chart); see generally BRUNO S. FREY \& ALOIS STUTZER, HAPPINESS AND ECONOMICS: HOW THE ECONOMY AND InSTITUTIONS AFFECT HumAN WELl-BEING (2001). The correlation is robust only up to an annual income of approximately $\$ 15,000$. Beyond that figure there is still an increase in reported wellbeing that comes from additional income, but those increases come at a steeply diminishing rate. Id. at 83.

32. See Tom Ginsburg, Democracy, Markets and Doomsaying: Is Ethnic Conflict Inevitable? BERKELEY J. INT'L L., 310 (2004) (reviewing AMY CHUA, WORLD ON FIRE: HOW EXPORTING FREE MARKET DEMOCRACY BREEDS ETHNIC HATRED AND GLOBAL INSTABILITY (2003)). On the history and theory of democracy, see generally John Dunn, SETting the People FreE: The Story of DEMOCRACY (2005).

33. See, e.g., Adam Przeworski, Michael E. Alvarez, Jose Antonio Cheibub \& FERnANdo Limongi, DemOCRACY AND DeVElopMent: PoliticAl InSTITUTIONS AND WellBEING IN THE WORLD, 1950-1990, 142-86 (2000) (discussing political regimes and economic growth).

34. See, e.g., KARL DE SCHWEINITZ JR., INDUSTRIALIZATION AND DEMOCRACY (1964) (arguing that historically democracy developed through economic gains of the commercial class and their subsequent demands for a larger share of political power); see generally Kenneth A. Bollen, Political Democracy and the Timing of Development, 44 AM. SOC. REV. 572 (1979) (arguing that greater state control of the economic system leads to lower levels of democracy in the political system); LARRY J. DiAMOND, JUAN J. LINZ \& SEYMOUR MARTIN LIPSET, Introduction: Comparing Experience with Democracy, in POLITICS IN DEVELOPING COUNTRIES: COMPARING EXPERIENCES WITH DEMOCRACY 1 (Larry J. Diamond et al. eds., 1990) (exploring links between politics and democracy in the developing world). 
The purpose in summarizing even these few studies on economic development and democracy is to invoke those goals as criteria for a principled approach to managing odious debt. Both development and democratization are valuable, and both of these goals are likely to be at issue in each instance in which a nation seeks to be excused from some portion of its sovereign debt. That is, odious debt is most likely to be an issue for developing countries that have recently shifted their regime from one of despotism to democracy.

\section{IV}

\section{THE PROBLEM OF THE OdIOUS CREDITOR}

Proposals for solving the odious debt problem should be seen not as purely legal doctrine, but as attempts to achieve admirable foreign policy goals related to development and democratization. It follows that international relations matter a good deal for understanding the feasibility of potential solutions: one must consider the incentives for major international players that would have to acquiesce to the formation and implementation of a new doctrine of odious debt. A particularly significant problem in this regard-one of increasing importance in the current international debate-is the problem of the "odious creditor": states that have no interest in advancing democratization goals but that are significant lenders to other states.

After much optimism in the 1990s about the spread of democracy, it is clear that dictatorships are playing an increasingly important role in the global political economy. China is a crucial player in that Chinese decisions to finance American debt enable American profligate macroeconomic policy to continue, in turn generating demand for Chinese goods. China now sits on $\$ 1.1$ trillion of U.S. dollar reserves and is using this to finance regimes that have trouble obtaining credit from the International Monetary Fund and other multilateral sources. ${ }^{35}$

Rich authoritarians are unlikely to acquiesce to a doctrine that penalizes other authoritarians. China has shown itself to be generally unconcerned about the character of regimes it deals with in its insatiable demand for raw resources. China is the single biggest supporter of the Sudanese government, which is enabling genocide in Darfur. Even if the democratic nations on the U.N. Security Council wished to move forward with aggressive sanctions against Sudan, the Chinese would likely block them ${ }^{36}$ Another example is the Chinese support for the regime in Angola, which is Africa's second largest producer of oil after Nigeria and has been described as "one of the most corrupt and

35. Moises Naim, Rogue Aid, ForeIGn Policy, Mar.-Apr. 2007, at 96.

36. See China, Russia Bar Sudan Sanctions, BBC NEws, Apr. 18, 2006, available at http://news/.bbc.co.uk/2/hi/africa/4917970.stm (discussing China's refusal to impose sanctions on Sudanese officers); John Prendergast \& Colin Thomas-Jensen, Blowing the Horn, ForEIGN AFFAIRS, Mar.-Apr. 2007, at 59, 73 (explaining Beijing's reluctance to lean on Khartoum). 
impoverished countries in the world. ${ }^{{ }^{37}}$ Corruption and transparency concerns led the International Monetary Fund to cease lending to the government, but China stepped in to provide finances, secured by Angola's oil reserves. ${ }^{38}$ China also recently hosted a summit for 1,500 leaders and forty-eight heads of state from of the African continent, including such luminaries as Zimbabwe's Robert Mugabe. ${ }^{39}$ China is the primary sponsor of the government in Myanmar, ${ }^{40}$ significantly hindering two decades of American attempts to turn that government into a pariah. China is thus an ally of many of the regimes that might be declared odious under current proposals, and it is in a particularly favorable position to extend credit to those regimes.

China is not the only autocracy in such a position. While less significant on a global scale, smaller countries such as Venezuela and Iran have emerged as regional powers whose coffers are filled with oil monies and who have limited interest in democratization at home. Venezuela's oil surpluses have been recycled to Cuba, providing much-needed hard currency that sustains the regime two decades after the end of the Soviet Union. ${ }^{41}$ The boom in oil and other "point-source" natural resources-those drawn from a narrow geographic area, which tend to be associated with negative governance outcomes like civil war and corruption-has empowered all kinds of governments and encouraged

37. John Reed, Angolan Oil Loan Likely to Raise Transparency Issues, FIN. TIMES, Oct. 11, 2005, at 13 (quoting the non-governmental organization Global Witness).

38. Id.; Angola: Oil Backed Loan Will Finance Recovery, IRIN Africa, Mar. 5, 2007, available at http://www.irinnews.org/report.aspx?reportid=53112. See generally Steve Kibble, Angola: Can the Politics of Disorder Become the Politics of Democratisation \& Development?, 109 REV. AFRICAN POL. ECON. 525, 528-29 (2006) (describing Chinese loans as undermining international leverage, undercutting civil society, and serving as core obstacles to development). We are grateful to our colleague Pat Keenan for drawing this issue to our attention and for providing extensive documentation.

39. See Simon Elegant, Beijing Hosts Africa's Leaders: Just Don't Mention Darfur, TIME.com, Nov. 3, 2006; see also Luis Ramirez, China Defends Decision to Invite Sudan, Zimbabwe to Africa Summit, VOICE OF AM., Nov. 3, 2006, available at http://www.voanews.com/tibetan/archive/200611/2006-11-03-voal.cfm.

40. See generally UN Votes to Put Burma on Agenda, BBC News, Sept. 16, 2006 (discussing China's opposition to the U.S.-backed placement of Burma on the Security council agenda), available at http://news.bbc.co.uk/2/hi/asia-pacific/5351246.stm; see also U.S. - CHINA ECONOMIC AND SECURITY REVIEW COMMISSION, 2006 REPORT TO CONGRESS, 78, 109th Cong. (2006), available at http://www.uscc.gov/annual_report/2006/annual_report_full_06.pdf (equating the strong economic relationship between China and Burma with "keeping the Burmese economy afloat in the face of international sanctions.").

41. See generally Michael Ross, Does Oil Hinder Democracy?, 53 World POLITICs 325, 356 (Apr. 2001) (concluding there is a negative correlation between a country with large number of oil reserves and democratic governance); CENTER FOR ADVANCED DEFENSE STUDIES [CADS], VENEZUELA'S GROWING APPETITE FOR REgIONAL POWER (2006), available at http://www.isn.ethz.ch/pubs/ph/ details.cfm?lng=en\&id=26991; John Simpson, Iran's Growing Regional Influence, BBC WORLD NEWS, Sept. 20, 2006, available at http://news.bbc.co.uk/2/hi/programmes/5363098.stm; see also CUBA Transition Project, How Venezuela Subsidizes the CAStro Regime, Issue 10 (2005), available at http://ctp.iccas.miami.edu/FACTS_Web/Cuba\%20Facts\%20Issue\%2010\%20April\% 202005.htm (estimating Cuba's total value of imported Subsidized Oil from Venezuela at $\$ 940$ million in 2004). 
odiousness. ${ }^{42}$ A distinctive characteristic of such resources is that they have a relatively low elasticity of demand, which means that the quantity demanded of those resources is relatively insensitive to changes in prices. As a result, regimes with oil (or diamonds, for example) have poor human rights records and are relatively insulated from international criticism and condemnation. ${ }^{43}$

There is no reason to think that any of these countries would support the emergence of an odious debt doctrine. China's foreign policy is based on longstanding concerns of sovereignty and noninterference in the internal affairs of other states. ${ }^{44}$ This matters a good deal, since, as a permanent member of the U.N. Security Council, China is in a position to block or slow the emergence of international legal doctrines that seek to punish regimes of any particular character. We think this fact poses a fatal objection to the proposal put forward by Professors Bolton and Skeel. ${ }^{45}$ Bolton and Skeel believe the United Nations Security Council can provide an effective forum for identifying and regulating odious regimes. They recognize that there will be some "false negatives" in the form of odious regimes not declared as such because of political considerations. $^{46}$ In our view, however, the real issue is whether there will be any "true positives." The Security Council is not an exclusively cooperative institution, but rather a complex arena of political competition and cooperation. One needs to make a strong affirmative case based on the incentives of its members to demonstrate that the Security Council can be an effective forum for advancing the odious debt proposal.

Even beyond political obstacles, the odious debt doctrine may strengthen the position of China and other odious creditors vis-à-vis authoritarian regimes. Dictators will seek to borrow from relatively benign creditors rather than risk non-recovery from Western sources with their moral agendas. And if Western powers stopped lending to such countries, China would be able to fill the void and gain significant political leverage over other autocracies. Lending from other governments can be crucial in maintaining odious regimes-in the case of Saddam's Iraq, only a small proportion of debt was held by private creditors. ${ }^{47}$

There is already some evidence that a club of autocracies is emerging. In Asia, the Shanghai Cooperation Organization, founded in 2001, brings together Russia, China, and various central Asian dictatorships to talk about common

42. Jonathan Isham et al., The Varieties of Resource Experience: How Natural Resource Export Structures Affect the Political Economy of Economic Growth (Middlebury College Discussion Paper No. 2003-08, Apr. 2003), available at http://papers.ssrn.com/sol3/papers.cfm?abstract_id=410364.

43. Id.; See, e.g., HUMAN Rights WATCH, SUDAN, OIL AND HUMAN RighTS (2003), available at http://www.reliefweb.int/library/documents/2003/hrw-sud-25nov.pdf (exploring how Sudan's poor human rights record was partially driven by the desire to control oilfields, and criticizing foreign government support throughout the human rights abuses).

44. Samuel S. Kim, The Development of International Law in Post-Mao China: Change \& Continuity, 1 J. CHINESE L. 117, 148-49 (1987) (describing the Five Principles of Peaceful Coexistence).

45. See Bolton \& Skeel, supra note 15.

46. Id.

47. Patricia Adams, Iraq's Odious Debts, Cato Institute Policy Analysis No. 526 (Sept. 2004) at 5, available at $\mathrm{http} / / / \mathrm{www} . c a t o . o r g / p u b s /$ pas/pa-526es.html. 
views and to participate in military cooperation. ${ }^{48}$ If, for example, Uzbekistan were declared an odious regime such that credits extended to it might not have to be repaid in the event the government fell, the regime would certainly still be able to attract capital and development assistance from Russia, China, and another potential member, Iran. The odious debt doctrine, perversely, could strengthen autocracies and contribute to their economic integration as a counterbalance to the industrial West.

The problem of the odious creditor ought to trouble those who are committed to the odious debt doctrine. Because China will likely block the formal emergence of universal norms against the collectability of odious debt, the doctrine will likely emerge only among a subset of countries, the industrial democracies, which no longer dictate the price of sovereign debt. To the degree the industrial democracies remove themselves from the global lending picture, they increase the incentives of a "rogue creditor" with deep pockets, such as China, to enhance its geopolitical and economic influence. The Washington Consensus may be giving way to a "Beijing Consensus." ${ }^{\text {"9 }}$ Whatever this means for economic well-being, this shift can hardly help the long-term cause of democracy.

\section{$\mathrm{V}$ \\ A Modest Solution to the Problem of Odious DebT}

So far we have argued that the odious debt proposal is best understood as part of the broader foreign policy objectives of economic development and democratization. Although a policy that would make odious debt uncollectible would, according to proponents, raise the cost of capital for authoritarians and prevent new democratic regimes from being burdened with heavy debt, it is unclear whether such a new legal doctrine can be created in a world of "odious creditors."

Even so, the modest proposal presented here could help advance some of the goals of the odious debt proposal without encountering some of the severe challenges to administrability raised above. Suppose that the international community identifies foreign debt as a crucial barrier to the democratization of a post-dictatorial regime-say, Iraq. Two distinct problems have to be faced: First, how can friends of development and democracy ensure that the country maintains a solid credit rating in the event that it defaults on its debt? One possibility would be for those friends to take over the debt directly through the

48. Charter members included China, Russia, Kazakhstan, Kyrgyzstan, Uzbekistan, and Tajikistan. Mutlaq Al-Qahtani, The Shanghai Cooperation Organization and the Law of International Organizations, 5 CHINESE J. INT'L L. 129, 130 (2006); see also Frederick W. Stakelbeck, Jr., The Shanghai Cooperation Organization, FRONT PAGE MAGAZINE, Aug. 8, 2005, available at http://www.frontpagemag.com/Articles//Printable.asp?ID=19041. See generally Richard Komaiko, The Great Game (unpublished manuscript, on file with authors).

49. See generally Randall P. PeERenboom, China Modernizes: Threat to the West or MODEL FOR THE REST? 1 (2007). 
IMF. Although this would relieve the new democracy of the burden of debt repayment, it does not address the second problem, the moral-hazard problem of prospective creditors. Those creditors would continue to extend credit to the authoritarian regime, even extending its lifespan, in confidence that the debt would be repaid after the regime fell.

To introduce real risk into the calculations of creditors, effective repudiation of the odious debt is needed-not merely transferring the debt to parties with pockets sufficiently deep to pay it off. Here, the best approach is not to set up an unwieldy new doctrine in international law, but simply to provide incentives in the marketplace to reduce the harm to poor countries that repudiate odious debts.

Modest steps can be taken to encourage selected, carefully identified recipient countries to repudiate the debt. The IMF or World Bank could offer insurance on future loans to be extended to the country after repudiation, thus reducing the interest-rate penalty the country will suffer as a consequence of reputational harm. A useful parallel can be found in the World Bank's Multilateral Investment Guarantee Agency (MIGA), established after several decades of discussion in $1986 .^{50}$ MIGA is designed to facilitate private investment in developing countries by offering investment insurance against a variety of "political" risks. ${ }^{51}$ An American equivalent is the Overseas Private Investment Corporation, an independent agency of the U.S. government that also offers insurance against the expropriation of invested capital by foreign governments. The proposal offered here, however, would be more limited, focusing on sovereign debt rather than on private-investment capital. The World Bank or IMF could set up an agency that would in essence guarantee debt repayment by selected sovereign borrowers. This debt insurance program would be applied only to very particular regimes emerging from particularly odious dictatorships. It does not require general legal criteria but rather specific political decisions within the context of multilateral lending agencies, and it compensates for reputational losses associated with repudiation. Decisions could be made relying on many of the criteria put forward in other proposals related to odious debt, voted on by a majority vote of international financial institution (IFI) shareholders. ${ }^{52}$

The insurance that would be offered would be designed to compensate for reputational losses associated with repudiation by new democracies emerging from odious dictatorships. It would apply only to new lending directed to those countries and would be designed to reduce the spread between interest rates demanded by creditors and those prevailing under market conditions. Because

50. Alex Khachaturian, Note: "Are We In Good Hands?" The Adequacy Of American and Multilateral Political Risk Insurance Programs In Fostering International Development, 38 U. CONN. L. REV. 1041, 1050 (2006).

51. These include currency inconvertibility, expropriation, and political violence. Id.

52. For a description of the criteria that might be used to define Odious Regimes, see Bolton \& Skeel, supra note 15. 
the new democracies will have recently repudiated all or some of the debt accumulated under the previous regime, we assume that lenders would demand higher interest rates on new lending. The proposed insurance scheme could either insure the entirety of the new loans, or simply target the additional interest rate so as to make the lender indifferent between lending to the new democracy or lending to another debtor in the marketplace.

One objection to our proposal is that of moral hazard. There is some risk under our proposal that new democracies may seek to incur "too much" new debt because of the implicit subsidy offered by the debt insurance. However, the IMF is already in a position to monitor debt levels as part of its mandate to manage balance of payments under the Articles of Incorporation. The World Bank is the body in the best position to monitor whether borrowing is being used for development purposes. Certainly there is no better-positioned set of institutions in the international arena than the IFIs to address the moral hazard concerns.

We believe the IMF and World Bank are better vehicles for addressing the odious debt problem than the United Nations. ${ }^{53}$ Potentially odious creditors wield veto power in the United Nations Security Council; the United Nations General Assembly is a highly politicized body in which nondemocracies have a strong voice. It is unreasonable to expect non-democracies to endorse a policy that is designed to promote democratization. The IMF and World Bank, on the other hand, are governed by Boards of Governors with weighted voting based on subscriptions paid or shares held. ${ }^{54}$ The largest five countries by voting weight in the IMF, for example, are the United States, Japan, Germany, the United Kingdom, and France.

Naturally, this proposal assumes that international institutions can effectively handle this set of goals. Currently, the articles of incorporation for both the IMF and World Bank do not include a mandate to encourage democratization. International financial institutions, and development assistance generally, create what might be called a "bilateral agency problem," involving citizens and governments in both donor and recipient countries. ${ }^{55}$ Citizens in one country support foreign aid and development for a variety of reasons-altruistic, ideational, and pecuniary. Their representatives, through political institutions, translate these preferences into foreign aid policy. This involves the transfer of resources to foreign countries, through a mix of international, bilateral, and private institutions, for spending on behalf of citizens in the recipient country.

An agency framework illuminates one feature of foreign aid, namely that it is given almost exclusively by democracies. The top aid-giving countries by

53. Cf. id.

54. International Bank for Reconstruction and Development Articles of Agreement, art. V.3; International Monetary Fund Articles of Agreement, art. XII.5.

55. See Peter Murrell, The Interaction of Donors, Contractors and Recipients, in THE INSTITUTIONAL ECONOMICS OF FOREIGN AID (Bertin Martens et al. eds., 2002). 
absolute dollars are the United States, Japan, the United Kingdom, Germany, and France, ${ }^{56}$ the top by percentage of Gross Domestic Product is Norway. ${ }^{57}$ Traditionally, and in contrast to the democratic nature of the donors, recipients have been selected without regard to the governmental structure of their regimes. ${ }^{58}$ Some of the biggest recipients of American foreign aid, for example, include Egypt and Pakistan. ${ }^{59}$

This asymmetry between donors and recipients-of democracies giving and lending money to non-democracies-matters for thinking about the odious debt problem. International financial institutions have not explicitly incorporated democracy into their decisionmaking criteria or goals. International financial institutions are ultimately creatures of their member governments, but they are several steps removed from the preferences of national citizens in donor countries. These institutions have their own structures and sets of incentives; as in any bureaucracy, individual incentives may not align with the nominal purpose of the institution. There are many concerns about the accountability of international bureaucracies, many of which have ultimately not been answered. ${ }^{60}$

56. See ORganization FOR ECONOMIC CO-OPERATION AND DEVElopment, OfFicial DEVELOPMENT ASSISTANCE DATA FOR 2005 3, available at http://www.oecd.org/dataoecd/52/18/ 37790990.pdf.

57. See Sanjeev Gupta, Catherine Patillo \& Smita Wagh, Are Donor Countries Giving More or Less Aid? 5 (IMF Working Paper No. 06/1, 2006), available at https://www.imf.org/external/pubs/ft/ wp/2006/wp0601.pdf.

58. To be fair, however, thinking about foreign aid as a bilateral agency problem illustrates the similarity across recipient regimes. No doubt the governing coalitions in all countries, both democratic and authoritarian, take at least a portion of the foreign aid for their own benefit and in order to keep together the governing coalition. But nations differ in the degree to which the aid is skimmed off. Probably there is less skimming in democracies than autocracies, although this is not categorically true. There are examples of developmental state autocracies that were, in fact, quite clean. Democracies suffer legion problems of interest-group politics, too; so one cannot simply assume that autocracies are worse. Autocracies, however, have greater variance. The main point is that the spending and borrowing in any recipient country is likely to be greater than the benefit received by the citizenry. This creates an agency problem endemic in the world of all foreign aid.

59. The top recipients in 2005 in order are Israel, Egypt, Afghanistan, Pakistan, Colombia, Sudan, Jordan, Uganda, Kenya, and Ethiopia. Afghanistan and Israel are the only democracies on the list. CONGRESSIONAL RESEARCH SERVICE REPORT: FOREIGN AID: AN INTRODUCTORY OVERVIEW OF U.S. PROGRAMS AND POLICY 18 (Jan. 19, 2005), available at http://www.italy.usembassy.gov/pdf/ other/98-916.pdf.

60. Cf. Anne-Marie Slaughter, The Accountability of Government Networks, 8 IND. J. GLOBAL LEGAL STUD. 347 (2000-2001). One particular problem is the threat of "negative net transfers." This idea draws on the fact that when international development lending institutions extend loans, the loans must eventually be paid back. In the early years of operating in a country, the amount of money going in will exceed the amount being paid back. As the country develops however, the recipient becomes more able to pay the money back and is less in need of new credits. When funds are extended across many countries, a development-lending institution may eventually have more funds coming in than going out in new loans. And this would mean that the institution was a net drain on the resources of developing countries. An international development institution drawing capital out of developing countries is unlikely to earn the support of the citizens of rich countries. Thus, IFIs are in continuous need of finding new targets for loan programs. See Paul Mosley, AID AND POWER: THE WORLD BANK AND POLICY-BASED LENDING 47 (2d ed. 1995). 
The odious debt problem thus focuses attention not only on the justice of having borrowers pay back lenders but also on the agency problem between rich world citizens and development institutions - a point that has been underappreciated in many odious debt discussions. Structuring less perverse incentives for development institutions will improve their role of monitoring the use of rich country citizen funds spent abroad.

In recent years, donors have begun to pay attention to the agency problems involved in giving foreign aid to nondemocracies. Most of the United States' increase in development aid in the past few years has gone into the Millennium Challenge Account ("MCA"), the Bush Administration's innovation in foreign aid. The Millennium Challenge Account Framework is designed to introduce a form of conditionality to the modern aid situation. ${ }^{61}$ Aid is targeted especially at countries that have already democratized somewhat and have made progress in such areas as corruption control, political rights, civil liberties, rule of law, voice, and accountability-governance criteria relevant to effective use of the aid dollar..$^{2}$

The MCA has been criticized in some quarters, and funds have been slow to flow under it. Nevertheless, the concept of aligning incentives among rich country citizens, development-institution bureaucrats, and citizens in recipient countries seems to have great promise. International financial institutions ought to consider the democratic prospects of recipient countries as well as those countries' development prospects in structuring policies. Setting up an institutional structure to facilitate selective repudiation of particularly odious debt by subsidizing future loans to the repudiating country will ultimately help the cause of democracy, advancing foreign policy as well as development goals.

Although odious debt comes in many forms, the presence of IFIs significantly changes market incentives, creating a moral hazard that might lead private banks to loan money to countries expecting an international bailout. ${ }^{63}$ The institutional incentives of the IFIs must be addressed in thinking about odious debt. The approach described in this article is more advantageous in that it focuses on the entities that have some control over debtor-state actions. ${ }^{64}$ And it does so in a way that enhances democratic accountability in rich countries as well as poor ones.

\section{VI \\ CONCLUSION}

Consideration of odious debt should focus on three features of the international context. First, the odious debt doctrine should be seen as part of

61. See, e.g., President George W. Bush, Remarks on Global Development at the Inter-American Development Bank (Mar. 14, 2002), available at http://www.whitehouse.gov/news/releases/2002/03/ 20020314-7.html.

62. The MCA also considers metrics on basic health and human services and economic freedom.

63. Kremer \& Jayachandran, supra note 15 , at 3.

64. Rasmussen, supra note 25 . 
an overall foreign-policy goal of democratization. Second, this focus calls into sharp relief the contrast between the behavior of democracies such as the United States and other major actors in the international sphere who have been only too happy to support the most odious of regimes. The problem of the "odious creditor" will be an increasingly important challenge as China becomes a major player in international financial markets. Achieving the goals of odious debt proponents requires consideration of this issue. Finally, a third feature of the international environment is the incentive structure of IFIs, whose presence creates a moral hazard for creditors.

Advancing the goals of the odious debt doctrine requires making democracy an element of lending decisions by IFIs. International financial institutions are, by their charter, politically neutral institutions, but they are not subject to conventional market discipline. In recent years, the World Bank has become extensively involved in governance-promotion activities, notwithstanding its mandate to avoid politics. In practice, IFIs ought to help advance the foreignpolicy objectives of their ultimate principals, the citizens of rich countries whose national budgets contribute to the overwhelming majority of funds given to IFIs. Making IFIs take democracy seriously will both enhance democracy in the developing world and alleviate the agency problem in donor countries.

A special fund designed to subsidize new lending by countries burdened with odious debt can help alleviate in a modest way some of the problems associated with earlier proposals. The ultimate decision to repudiate debt would still be made by the new democracy, but the costs of such repudiation would be reduced. Knowing this, creditors would think twice about lending to odious dictatorships, being less confident that a bailout would occur and having to consider the possibility of repudiation. No doubt the proposal will leave some moral hazard in place. Some creditors will take the risk, and odious dictators will continue to find sources of capital. At the margin, however, getting IFIs to better structure the incentives for new democracies will advance some of the goals of those who wish to deal with the odious debt problem. 